\title{
Methane and Nitrous Oxide Emissions from Agriculture on a Regional Scale
}

\author{
Agnieszka Wysocka-Czubaszek ${ }^{1 *}$, Robert Czubaszek ${ }^{1}$, \\ Sławomir Roj-Rojewski', Piotr Banaszuk ${ }^{1}$ \\ 1 Department of Agri-Food Engineering and Environmental Management, Faculty of Civil and Environmental \\ Engineering, Białystok University of Technology, ul. Wiejska 45A, 15-351 Białystok, Poland \\ * Corresponding author's e-mail: a.wysocka@pb.edu.pl
}

\begin{abstract}
Nowadays, agriculture has to meet the growing food demand together with high requirements of environmental protection, especially regarding the climate change. The greenhouse gas emissions differ not only on a global, but also on a regional scale, and mitigation strategies are effective when they are adapted properly. Therefore, the aim of this paper is to present the results of methane $\left(\mathrm{CH}_{4}\right)$ and nitrous oxide $\left(\mathrm{N}_{2} \mathrm{O}\right)$ emissions inventory on a regional level in Poland in years 1999-2015. The $\mathrm{CH}_{4}$ and $\mathrm{N}_{2} \mathrm{O}$ emissions were calculated according to the methodology used by the National Centre for Emissions Management (NCEM) for national inventory for United Nations Framework Convention on Climate Change and Kyoto Protocol. The data were taken from Central Statistical Office of Poland. The $\mathrm{CH}_{4}$ emissions in all studied years varied strongly between voivodeships and ranged from $5.6-7.5 \mathrm{Gg}$ $\mathrm{y}^{-1}$ in the Lubuskie Voivodeship to 84.8-104.3 $\mathrm{Gg} \mathrm{y}^{-1}$ in the Mazowieckie Voivodeship. While in most voivodeships the $\mathrm{CH}_{4}$ emissions dropped down, in Podlaskie, Warmińsko-Mazurskie, and Wielkopolskie voivodeships, the emissions of this gas increased significantly as a consequence of the development of dairy and meat production. In 1999, the highest $\mathrm{N}_{2} \mathrm{O}$ fluxes were calculated for the Wielkopolskie $\left(5.7 \mathrm{Gg} \mathrm{y}^{-1}\right)$, Mazowieckie $\left(4.8 \mathrm{Gg} \mathrm{y}^{-1}\right) \mathrm{Ku}-$ jawsko-Pomorskie $\left(3.5 \mathrm{Gg} \mathrm{y}^{-1}\right)$ and Lubelskie $\left(3.3 \mathrm{Gg} \mathrm{y}^{-1}\right)$ voivodeships, while in 2015, the highest nitrous oxide emissions were calculated for the Wielkopolskie $\left(7.3 \mathrm{Gg} \mathrm{y}^{-1}\right)$, Mazowieckie $\left(5.5 \mathrm{Gg} \mathrm{y}^{-1}\right)$, Kujawsko-Pomorskie (4.1 $\left.\mathrm{Gg}^{-1}\right)$ and Podlaskie (4.1 $\left.\mathrm{Gg} \mathrm{y}^{-1}\right)$ voivodeships. In the studied period, the contribution of $\mathrm{N}_{2} \mathrm{O}$ emissions from crop production increased in almost all voivodeships except the Podlaskie, Lubuskie and Warmińsko-Mazurskie regions. The growth in emissions from mineral fertilization and crop residue incorporation, together with the increase of emission from the animal sector in some regions of Poland, resulted in the higher national emission of nitrous oxide in the period of 1999 to 2015. Although there is a range of GHG reduction possibilities, the mitigation should be adapted with caution, on the basis of precisely calculated GHG emissions. The best management practices, if followed carefully, may reduce the environmental burden of the agricultural production and enhance its profitability.
\end{abstract}

Keywords: methane emissions, nitrous oxide emissions, agriculture

\section{INTRODUCTION}

Recently, the greenhouse gas (GHG) emissions from agriculture have received much attention because of the worldwide GHG reduction policy and predicted growing food demand in following years, caused by an increase in population to 9.8 billion in 2050 [UN 2017]. Agriculture contributes $24 \%$ to the global GHG emissions [IPCC 2014] and this sector is the largest contributor to the global emissions of non- $\mathrm{CO}_{2}$ greenhouse gases. Globally increasing food demand may re- sult in ca. 77\% rise of GHG related to agriculture, as a consequence not only of the growing livestock population which is expected to induce an increase of emissions from enteric fermentation by $22 \%$ in the period from 2005 to 2030 [EPA 2012], or fertilizers usage but also as a result of deforestation and further mechanization [Bajzelj et al. 2014]. Agriculture is responsible for more than $81 \%$ of total global anthropogenic nitrous oxide $\left(\mathrm{N}_{2} \mathrm{O}\right)$ emissions [Isermann 1994] and 43\% of the total anthropogenic methane $\left(\mathrm{CH}_{4}\right)$ emissions [Turner et al. 2015]. Enteric fermentation 
in ruminant animals and animal waste processing, besides rice cultivation and other agricultural practices, are the main sources of methane emissions [Yusuf et al. 2012]. The $\mathrm{N}_{2} \mathrm{O}$ is mainly released from cultivated soils, because of increased inputs of $\mathrm{N}$ fertilizers, animal wastes and biological N fixation [IPCC 2014]. With their high global warming potential, nitrous oxide and methane are now one of the most concerned greenhouse gases and agriculture is recognized as their main source [Zhou et al. 2007; Leip et al. 2011; Hou et al. 2015].

Although in EU-28, the emissions from livestock and crop production dropped down of almost a quarter (23.8\%) in the period between 1990 and 2012 [Eurostat 2015], the total emission from world agriculture actually grew by ca. $14 \%$ from 2001 to 2011 [FAO 2016]. Nowadays, Asia is the largest food consumer and produces the highest amounts of GHG from agriculture; however, in next three decades, the growing food demand in Africa and South America, together with increasing meat amount in a diet, will cause a substantial increase in the GHG emissions from agriculture in those regions of the world [Verge et al. 2007].

The differences in the GHG emissions are not only observed on a global level, but also on the level of the single country. In the EU-15, the agricultural $\mathrm{CO}_{2-\mathrm{eq}}$. fluxes were the highest in the Netherlands and Belgium, medium fluxes arose in north-eastern France, Denmark, Switzerland, north-western and southern Germany, and northern parts of Spain and Italy, while moderately low emissions characterized most of France, the Mediterranean, Sweden and Finland [Freibauer 2003]. In Germany, the GHG emissions from agriculture varied strongly between regions and ranged from 3.7 $\mathrm{MgCO}_{2^{-\mathrm{eq}}}$ ha $^{-1}$ to $8.2 \mathrm{Mg} \mathrm{CO}_{2^{-\mathrm{eq}}}$ ha $^{-1}$, depending on stocking rates [Neufeldt et al. 2006]. These differences point out the importance of regionally targeting GHG mitigation policies and strategies. However, most GHG inventories are prepared on the national level, especially in those countries which have ratified the United Nations Framework Convention on Climate Change [UNFCCC 1997] and are now obligated to provide the annual report on their GHG emissions. This may impede targeting the regional policies towards climate protection, especially in those countries where agriculture is still developing or transforming.

Therefore, the aim of this paper is to present the results of methane and nitrous oxide emissions inventory on a regional level in Poland, in years
1999-2015. In addition, the emissions of both gasses were calculated per EUR 1,000 of investment layouts and market output in agriculture.

\section{METHODS}

The methane emissions for years 1999-2015 in all 16 voivodeships of Poland were calculated according to the methodology used by the National Centre for Emissions Management (NCEM) for national inventory for United Nations Framework Convention on Climate Change and Kyoto Protocol. According to the National Inventory Report 2016 (NIR 2016) [NCEM 2016], the main sources of $\mathrm{CH}_{4}$ emissions in the agriculture sector are: the enteric fermentation from ruminant animals, manure management, and burning of agricultural residues; however, the latter is responsible only for $0.2 \%$ of the $\mathrm{CH}_{4}$ emissions in Poland [NCEM 2016] and therefore was excluded from calculations. The Tier 1 method given by Intergovernmental Panel on Climate Change (IPCC) with emission factors (EF) taken from IPCC Guidelines for National Greenhouse Gas Inventories [IPCC 2006] was used to calculate the methane emissions from enteric fermentation of goats, horses, sheep and swine. The Tier 2 method with emission factors estimated for Poland [NCEM 2016] was taken to estimate the $\mathrm{CH}_{4}$ emissions from the enteric fermentation of cattle. Similarly, the Tier 2 method was used to calculate the methane emissions from manure management of cattle and swine, whereas the Tier 1 method was taken for the $\mathrm{CH}_{4}$ emissions from manure management of horses, goats, sheep and poultry. The emission factors for horses, goats, sheep and poultry were taken from IPCC [2006] and the EF for cattle and swine were taken from National Inventory Report [NCEM 2016].

The nitrous oxide emissions from manure management were estimated as direct and indirect ones. The methodology from IPCC Guidelines [2006] was used for calculating the direct emissions. The fraction of the animal waste management system (AWMS) and country-specific annual average nitrogen excretion per head of livestock (Nex) were taken from NIR 2016 [NCEM 2016]. The indirect $\mathrm{N}_{2} \mathrm{O}$ emissions related to $\mathrm{N}$ volatilization and $\mathrm{N}$ leaching and runoff from manure were calculated according to IPCC Guidelines [2006] with default emission factors, but AWMS fractions, country-specific Nex were 
taken from NIR 2016 [NCEM 2016]. The nitrous oxide emissions include the direct emissions from cultivated soils related to organic and inorganic $\mathrm{N}$ fertilizers use, urine and dung deposition by grazing animals, incorporation of crop residues into the soil, mineralization or immobilization of $\mathrm{N}$ associated with the loss or gain of soil organic matter, cultivation of organic soils, and indirect emissions from atmospheric deposition and nitrogen leaching as well as runoff from soils. The direct emissions from mineralization or immobilization of $\mathrm{N}$ associated with loss or gain of soil organic matter and from the cultivation of organic soils were excluded because of the lack of data. The $\mathrm{N}_{2} \mathrm{O}$ emissions were estimated according to formulas and with EFs taken from IPCC Guidelines [2006]. Only in the case of crop residues, the data on the $\mathrm{N}$ content in the above-ground residues, the ratio of above-ground residues to harvested yield and fraction of above-ground biomass removed from the field as a crop product were country-specific and, therefore, were taken from NIR 2016 [NCEM 2016].

Additionally, the methane and nitrous oxide emissions in 2015 were recalculated per EUR 1000 investment outlays and market outputs. The mitigation strategies and options that could be adopted were described in the last part of this paper.

The data on the number of animals, the area of agriculture land, investment outlays, market outputs and other statistical data were taken from Central Statistical Office of Poland, namely the statistical yearbook of the regions - Poland in years 1999-2016 and Local Data Bank.

\section{RESULTS AND DISCUSSION}

\section{Methane and nitrous oxide emissions}

The $\mathrm{CH}_{4}$ emissions in all studied years varied strongly between voivodeships and ranged from 5.6-7.5 $\mathrm{Gg} \mathrm{y}^{-1}$ in the Lubuskie Voivodship to $84.8-104.3 \mathrm{Gg} \mathrm{y}^{-1}$ in the Mazowieckie Voivodship. In most voivodeships, the annual emissions were less than $60 \mathrm{Gg}$, but in 3 regions, namely in the Mazowieckie, Wielkopolskie and Podlaskie voivodeships, they exceeded this value by ca. 40 $\mathrm{Gg}, 30 \mathrm{Gg}$ and $20 \mathrm{Gg}$, respectively (Figure 1).

Over 16 years, the $\mathrm{CH}_{4}$ emissions in 2 voivodships were on a stable level (Mazowieckie and Kujawsko-Pomorskie), in 3 regions, they have increased (Podlaskie, Warmińsko-Mazurskie and
Wielkopolskie) and in the other 11 provinces, they have decreased (Figure 1). The most pronounced decrease of methane was observed in the Podkarpackie, Małopolskie and Świętokrzyskie voivodeships by $70 \%, 55 \%$ and $49 \%$, respectively. These three voivodships are characterized with medium conditions for agriculture, which is expressed by index for the evaluation of the natural capability of agricultural areas (WRPP) equal to 70.4 points for the Podkarpackie voivodeship and 69.3 points for the Małopolskie and Świętokrzyskie voivodeships, higher than the mean WRPP for Poland, which is equal to 66.0 points [Stuczyński et al. 2000]. However, traditionally small farms, less than 5 ha prevail in those regions, with the agricultural production focused on supplying owners with the sale of surpluses on the local market. From the year 2000, the decrease of small farms engaged in livestock farming has been observed, as a result of high production costs and easily available meat and dairy products on the local market from bigger producers [Kulikowski 2010]. In some parts of the voivodeships, the rural areas are under the pressure of urban sprawling of bigger cities and the population living in the vicinity of large cities seeks employment there. The mountainous parts of those regions are of high natural value but with unfavourable conditions for agriculture production, which results in a shift from agriculture to tourism as the main source of income [MODR 2007]. In 5 voivodeships, namely Śląskie, Lubelskie, Dolnośląskie, Zachodniopomorskie and Opolskie, the $\mathrm{CH}_{4}$ emissions dropped by $27-43 \%$. The Opolskie, Dolnośląskie and Lubelskie voivodships are characterized with good natural conditions for agriculture and the highest WRPP equal to 81.8 points, 74.9 points, and 74.1 points, respectively [Stuczyński et al. 2000]. In the Dolnośląskie and Opolskie voivodeships, which are characterized with good quality of soils, farmers traditionally specialize in crop production. In the studied period, cereals and rape dominated in the sowing area structure. A similar situation was observed in the Zachodniopomorskie Voivodeship, even though this region was characterized by worse natural conditions for agriculture (WRPP 67.5 points); however, it was characterized with larger farms and high organization of production [Kopiński 2009]. In the Lubelskie and Śląskie voivodeships, where rather small farms prevail but soils are of good quality, the agricultural production shifted towards cereals with reduction 


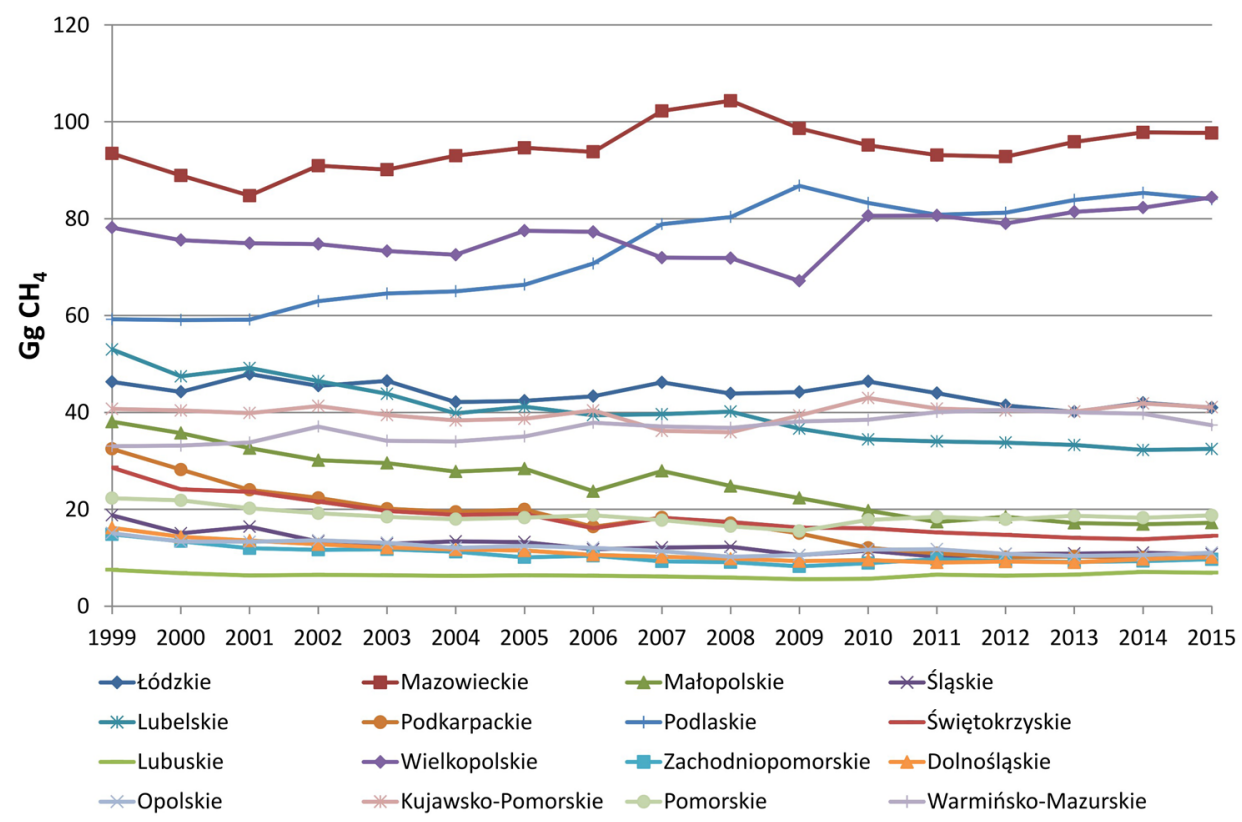

Figure 1. The $\mathrm{CH}_{4}$ emissions from agriculture in 16 voivodeships in years 1999-2015

of livestock, traditionally supplying owners demand. In the Pomorskie, Łódzkie and Lubuskie voivodeships, the reduction of $\mathrm{CH}_{4}$ emissions was low and equal to $8-16 \%$. This is due to the low organization of animal production, because in these regions crop production prevails. In two voivodeships, the emissions are stable due to traditionally high animal production, in the Mazowieckie Voivodeship cattle breeding prevail and in the Kujawsko-Pomorskie voivodeship, swine production is dominant.

While in most voivodeships the $\mathrm{CH}_{4}$ emissions dropped, in the Warmińsko-Mazurskie, Wielkopolskie and Podlaskie voivodeships the emissions of this gas increased significantly, especially in the case of Podlaskie Voivodeship (from $59.2 \mathrm{Gg} \mathrm{CH}_{4}$ in 1999 to $84 \mathrm{Gg} \mathrm{CH}_{4}$ in 2015 , i.e. an increase by $30 \%$ ). Those voivodeships traditionally specialized in milk and beef production were responsible for $29 \%$ national methane emissions from agriculture in 1999 and in 2015, these regions contributed to $39 \%$ of national fluxes. The Podlaskie Voivodeship characterized with poor, very acidic and acidic soils, as well as high percentage of grasslands and rather cold and harsh climate with short vegetation period [Filipiak, Ufnowska 2002] expressed by the lowest WRPP in the country (55.0 points) has traditionally specialized and in - recently intensified - milk production, which is the most suitable agricultural sector in climatic and soil conditions of this region. In the Warmińsko-Mazurskie Voivodeship, the intensification of animal production and specialization in milk production has been pronounced in years 2005-2007 and since then the number of cattle has been growing in this region.

Nitrous oxide is emitted in much smaller quantities than methane, but its global warming potential (GWP) equals to 310 [IPCC 2006] which makes $\mathrm{N}_{2} \mathrm{O}$ a very important part of the GHG budget. In 1999, the highest $\mathrm{N}_{2} \mathrm{O}$ fluxes were calculated for the Wielkopolskie $\left(5.7 \mathrm{Gg} \mathrm{y}^{-1}\right)$ and Mazowieckie (4.8 $\left.\mathrm{Gg} \mathrm{y}^{-1}\right)$ voivodeships with the Kujawsko-Pomorskie $\left(3.5 \mathrm{Gg}^{-1}\right)$ and the Lubelskie (3.3 $\left.\mathrm{Gg} \mathrm{y}^{-1}\right)$ voivodeships as next two biggest emitters (Figure 2). In 2015, the highest nitrous oxide emissions were calculated for the Wielkopolskie (7.3 $\mathrm{Gg} \mathrm{y}^{-1}$ ), Mazowieckie (5.5 Gg $\left.\mathrm{y}^{-1}\right)$, Kujawsko-Pomorskie (4.1 $\mathrm{Gg} \mathrm{y}^{-1}$ ) and Podlaskie $\left(4.1 \mathrm{Gg} \mathrm{y}^{-1}\right)$ regions. These four voivodeships are responsible for $47 \%$ of the national $\mathrm{N}_{2} \mathrm{O}$ fluxes from agriculture. In 1999, similar amounts of $\mathrm{N}_{2} \mathrm{O}$ were emitted from both the animal production, including manure management and organic fertilization, and crop production involving crop residues incorporation and mineral fertilization in the Wielkopolskie, Mazowieckie, Śląskie, Lubelskie and Podlaskie voivodeships. In the Łódzkie, Małopolskie, Świętokrzyskie and Kujawsko-Pomorskie voivodeships, the $\mathrm{N}_{2} \mathrm{O}$ emissions originating from crop production were higher, while in the Podkarpackie Voivodeship, much higher $\mathrm{N}_{2} \mathrm{O}$ emissions originated from animal production. In six voivodeships, the nitrous 


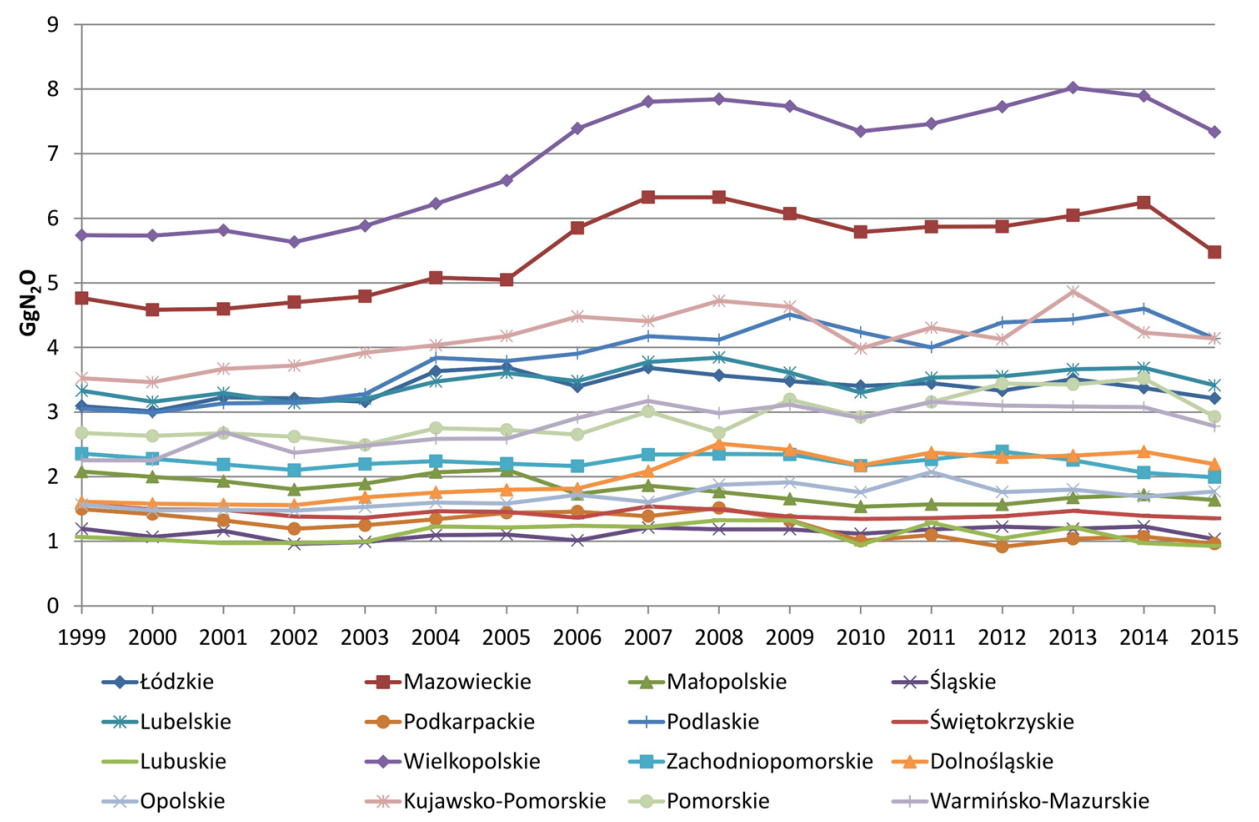

Figure 2. The $\mathrm{N}_{2} \mathrm{O}$ emissions from agriculture in 16 voivodeships in years 1999-2015

oxide emitted from crop production doubled the emissions from the animal sector.

In the period of 1999-2015, the contribution of $\mathrm{N}_{2} \mathrm{O}$ emissions from crop production increased in almost all voivodeships except the Podlaskie, Lubuskie and Warmińsko-Mazurskie regions. This increase is mainly due to a drop down in livestock number, even though the growth in milk production per cow from $3627 \mathrm{~L} \mathrm{cow}^{-1}$ year $^{-1}$ in 1999 to $4908 \mathrm{~L} \mathrm{cow}^{-1}$ year ${ }^{-1}$ in 2014 was observed. Although the sown area decreased from 12,585,200 ha in 1999 to $10,753,000$ ha in 2015 , the increase of fertilization rate from $87 \mathrm{~kg} \mathrm{ha}^{-1}$ to $123 \mathrm{~kg} \mathrm{ha}^{-1}$ and changes in crop structure resulted in the growth of $\mathrm{N}_{2} \mathrm{O}$ emissions from mineral fertilizers in 13 voivodeships (Figure 2). The growth in emissions from mineral fertilization and crop residue incorporation, together with the increase of emission from the animal sector in some regions of Poland, resulted in the higher national emission of nitrous oxide in the period of 1999 to 2015.

\section{Methane and nitrous emissions in relation to investment outlays}

The investment outlays in agriculture tend to grow quite rapidly in Poland. In the year 2000 in agriculture, the investments in buildings and technical equipment were similar (EUR $170,000,000)$ to each other and almost tripled the investment outlays in transport equipment (EUR 60,000,000). However, in years 2013-2015 the investments in buildings (EUR 547,000,000 in 2015) exceeded those in technical equipment (EUR 420,000,000 in 2015). In the year 2000 the lowest (less than EUR 20,000,000) investment outlays were found in the Świętokrzyskie, Małopolskie, Śląskie, Lubuskie and Podkarpackie voivodeships, the investments outlays on level EUR 20,000,000-30,000,000 were in the Lubelskie, Warmińsko-Mazurskie and Opolskie voivodeships, while investments in range of EUR $30,000,000-40,000,000$ were done in the Zachodniopomorskie, Podlaskie, Łódzkie, Dolnośląskie, Pomorskie and Kujawsko-Pomorskie voivodeships (Figure 3). The highest total costs were found in Wielkopolskie (EUR 67,000,000) and Mazowieckie (EUR 71,400,000) voivodeships [CSO 2016]. In 2015, the investment outlays were the still lowest in the same voivodeships, while in the regions such as Lubelskie, WarmińskoMazurskie and Podlaskie, the investments increased more than in other voivodeships, only the Wielkopolskie and Mazowieckie regions were still characterized with the highest total expenditures, which almost doubled the investments in the Lubelskie Voivodeship, the third region with the highest investment outlays (Figure 4).

The methane emissions per EUR 1,000 of investment outlays in 2015 were the highest in the Podlaskie voivodeship ( $880 \mathrm{~kg} \mathrm{CH}_{4}$ per EUR $1,000)$ and doubled the average for Poland $(417 \mathrm{~kg}$ $\mathrm{CH}_{4}$ per EUR 1,000). The $\mathrm{CH}_{4}$ emissions per EUR 1,000 were higher than the average for Poland 


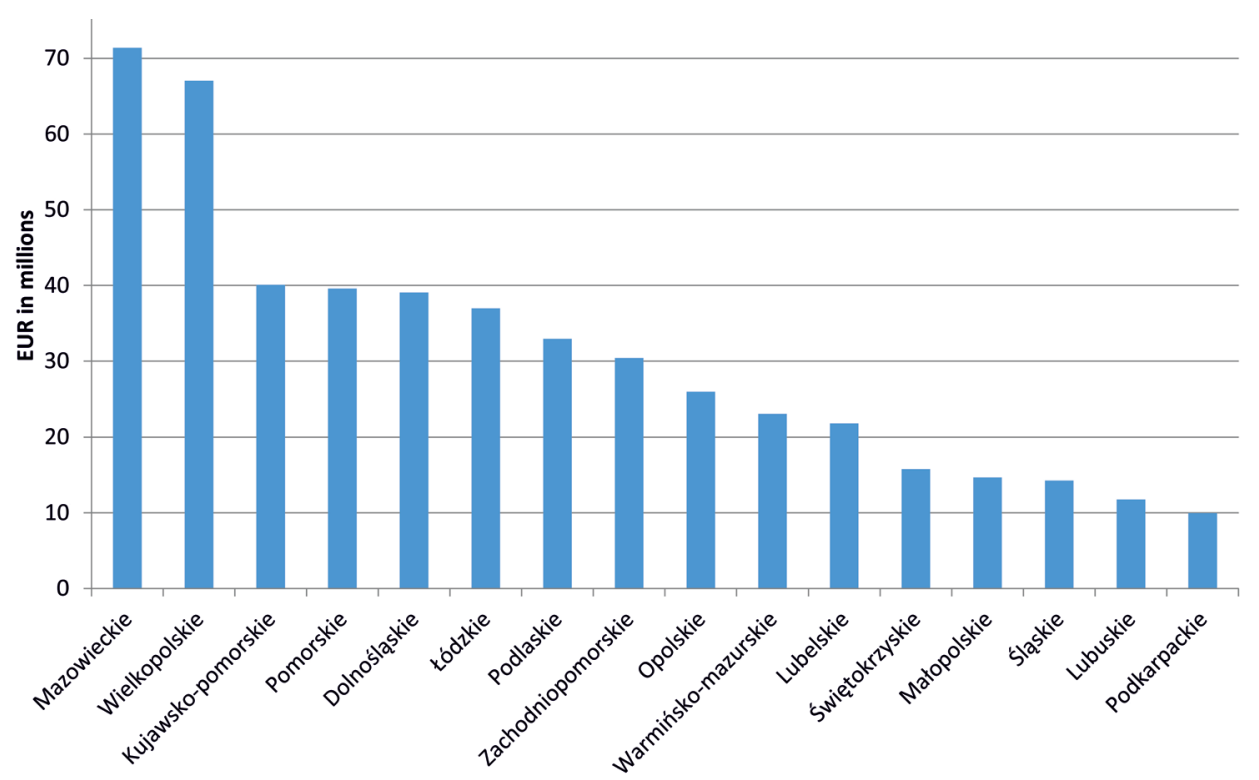

Figure 3. Investment outlays in agriculture in 16 voivodeships in the year 2000 [CSO 2016]

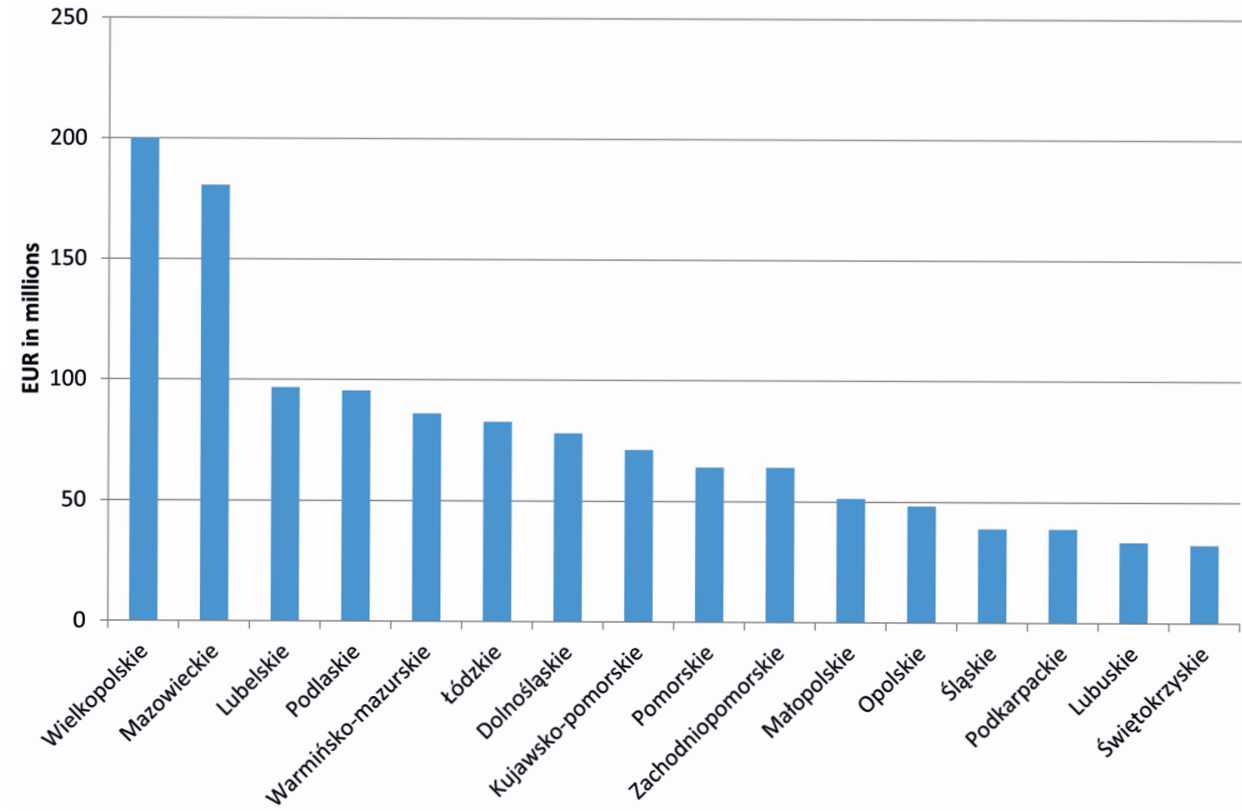

Figure 4. Investment outlays in agriculture in 16 voivodeships in the year 2015 [CSO 2016]

also in the Kujawsko-Pomorskie, Mazowieckie, Łódzkie, Świętokrzyskie, Warmińsko-Mazurskie and Wielkopolskie voivodeships (Figure 5) including those with high investment outlays like the Wielkopolskie and Mazowieckie regions, but also the ones with rather low investment expenditure such as the Świętokrzyskie Voivodeship.

The highest nitrous oxide emissions per EUR 1,000 (58 $\mathrm{kg} \mathrm{N}_{2} \mathrm{O}$ per EUR 1,000) in the country (Figure 6) are in the Kujawsko-Pomorskie Voivodeship. The Pomorskie $\left(46 \mathrm{~kg} \mathrm{~N}_{2} \mathrm{O}\right.$ per EUR 1,000) and Podlaskie $\left(43 \mathrm{~kg} \mathrm{~N}_{2} \mathrm{O}\right.$ per EUR 1,000) voivodeships were next two re- gions with the highest $\mathrm{N}_{2} \mathrm{O}$ emissions per EUR 1,000 of investment expenditure. This parameter was much lower than the average for Poland in the Mazowieckie Voivodeship (30 kg $\mathrm{N}_{2} \mathrm{O}$ per EUR 1,000), where investments are one of the highest in the country.

It must be emphasized that high investment expenditures in the regions specialized in dairy production may be related to the construction of a new structure for cattle breeding, while in the regions specialized in crop production this type of investment may be lower. In this sector, the emission rates are mainly related to the crop 


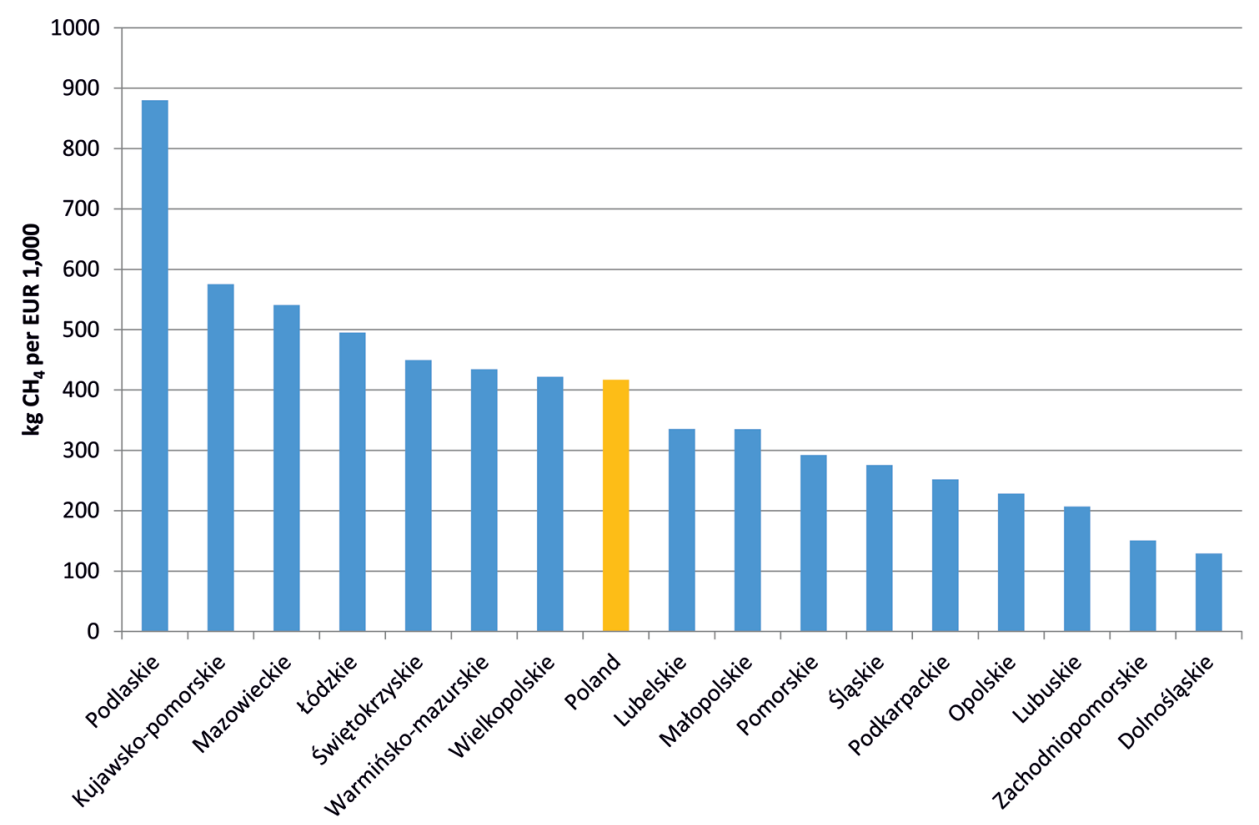

Figure 5. The methane emissions per EUR 1,000 of investment outlays in the year 2015

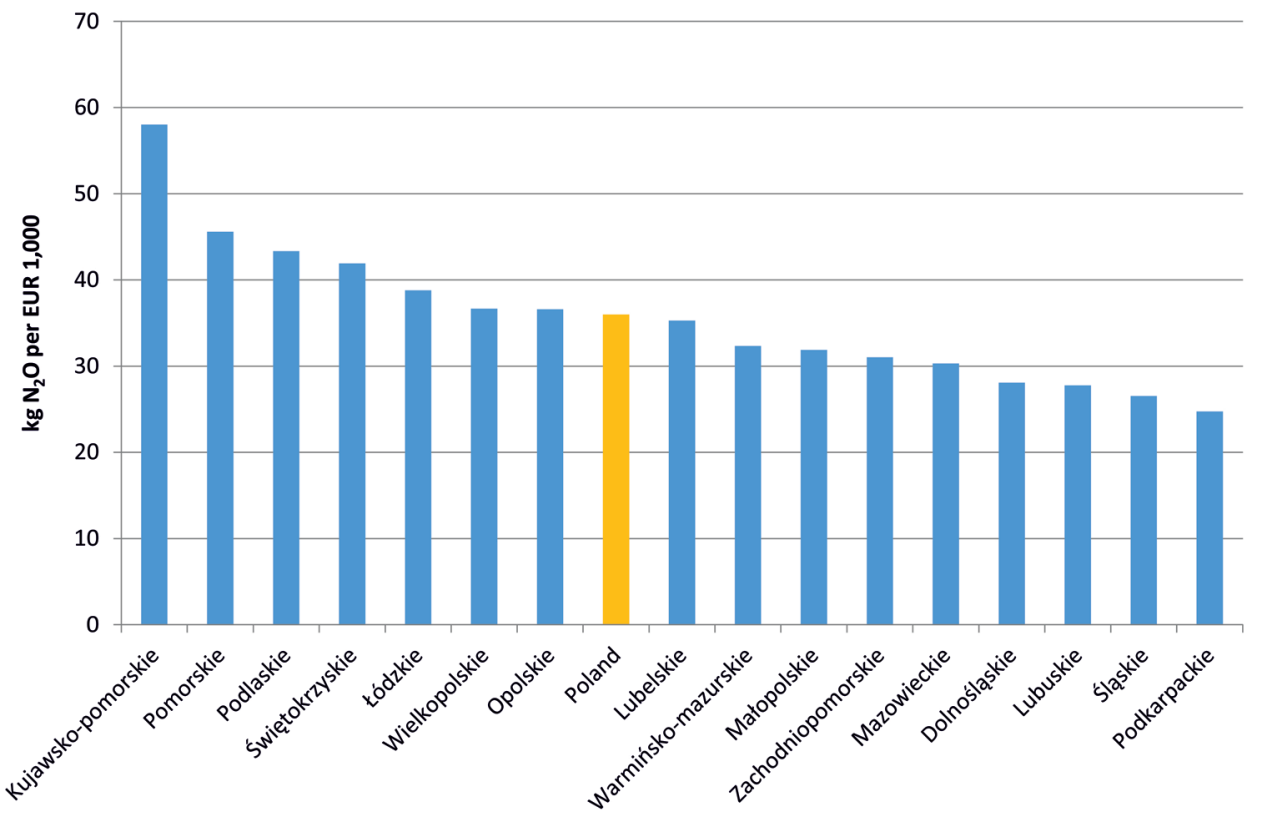

Figure 6. The nitrous oxide emissions per EUR 1,000 of investment outlays in the year 2015

structure and fertilization, while in the voivodeships specialized in the animal production, the amount of emitted GHG is associated with livestock number and structure.

\section{Methane and nitrous emissions in relation to market outputs}

The emissions per EUR 1,000 of market output reveal the environmental burden of agricultural products. In 2015, the highest $\mathrm{CH}_{4}$ emissions per EUR 1,000 were calculated for the Podlaskie
(67 $\mathrm{kg} \mathrm{CH}_{4}$ per EUR 1,000) and Wielkopolskie (48 $\mathrm{kg} \mathrm{CH}_{4}$ per EUR 1,000) voivodeships. Much lower levels, almost equal to the mean for Poland (28 $\mathrm{kg} \mathrm{CH}_{4}$ per EUR 1,000), were obtained for the Mazowieckie, Małopolskie, WarmińskoMazurskie, Kujawsko-Pomorskie, Podkarpackie, Łódzkie and Śląskie voivodeships (Figure 7).

In 2015, the highest $\mathrm{N}_{2} \mathrm{O}$ emissions per EUR 1,000 were calculated for the Wielkopolskie (4.17 $\mathrm{kg} \mathrm{N} \mathrm{N}_{2} \mathrm{O}$ per EUR 1,000), Podlaskie $\left(3.32 \mathrm{~kg} \mathrm{~N}_{2} \mathrm{O}\right.$ per EUR 1,000), Opolskie (3.02 $\mathrm{kg} \mathrm{N}_{2} \mathrm{O}$ per EUR $1,000)$ and Pomorskie $\left(2.94 \mathrm{~kg} \mathrm{~N}_{2} \mathrm{O}\right.$ per EUR 


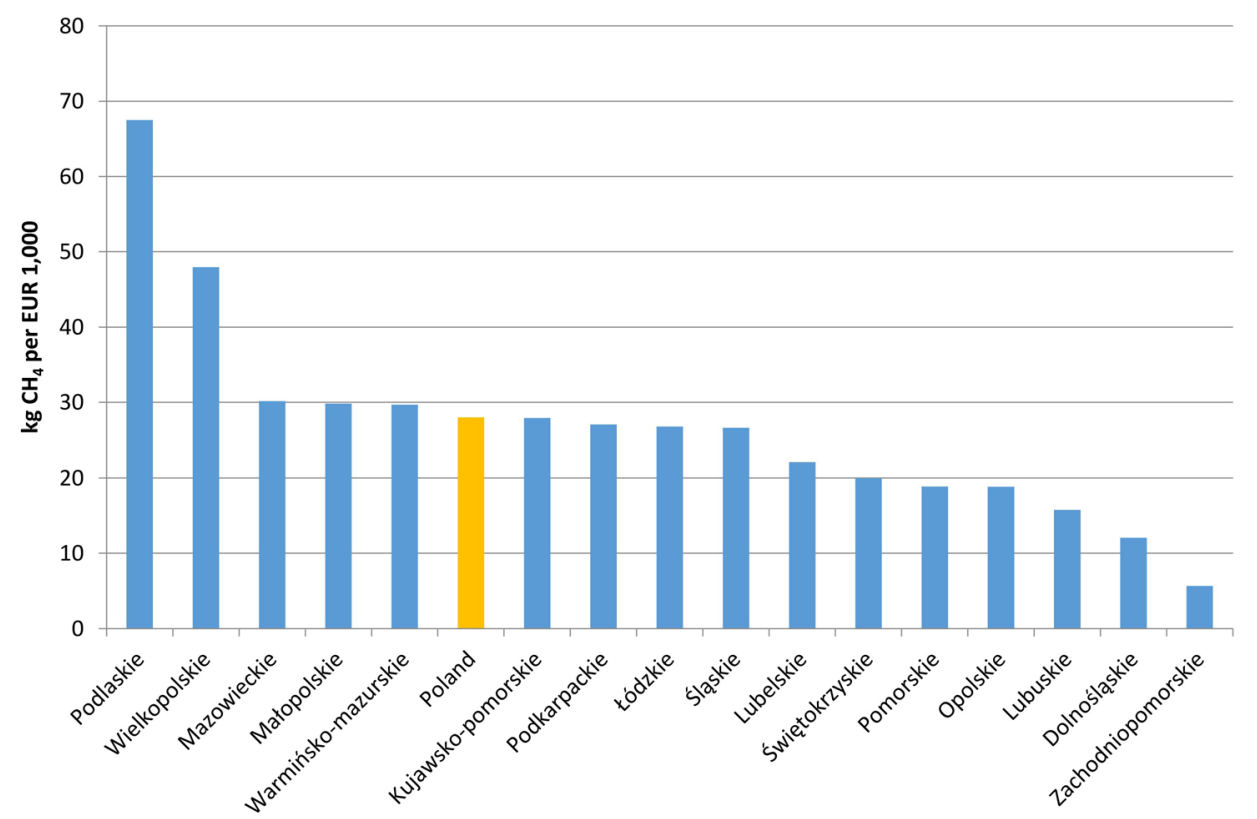

Figure 7. The methane emissions per EUR 1,000 of market outputs in the year 2015

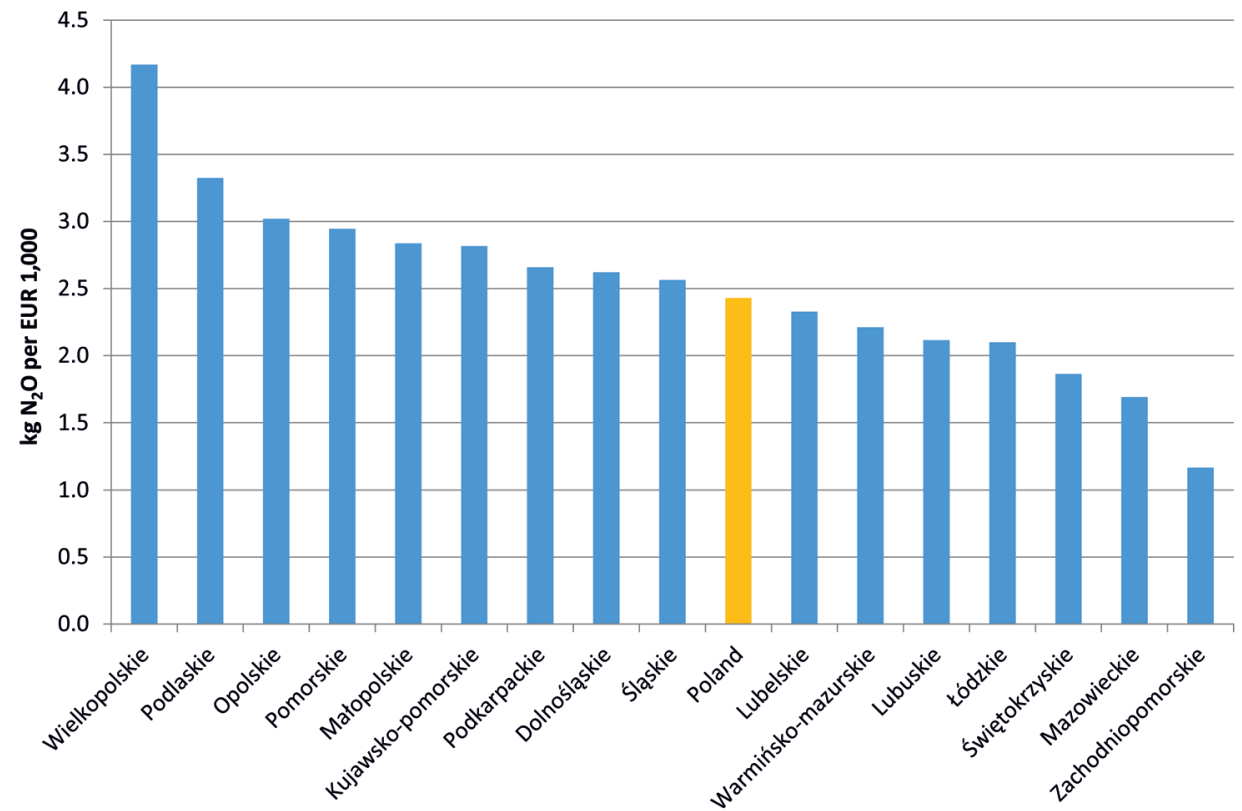

Figure 8. The nitrous oxide emissions per EUR 1,000 of market outputs in the year 2015

1,000) voivodeships (Figure 8). For five more voivodeships, namely the Małopolskie, Kujawsko-Pomorskie, Podkarpackie, Dolnośląskie and Śląskie region, this parameter was higher than the mean for Poland $\left(2.43 \mathrm{~kg} \mathrm{~N}_{2} \mathrm{O}\right.$ per EUR 1,000).

\section{Mitigation of methane and nitrous oxide emissions from agriculture}

The regional differences in the GHG production should be reflected in specific mitigation strategies targeting the main sources of emis- sions. In the regions specialized in meat and dairy production, such as the Mazowieckie, Podlaskie and Wielkopolskie voivodeships, the measures related to livestock breeding and manure management are the most important. One option is an intensification of dairy production which benefits in lower GHG emission per unit of milk. However, this measure may decouple the animal production from crops and further disturb the nutrient cycling [Zhang et al. 2017]. Industrialization may also increase pollution per unit area, raise phosphorus and nitrogen losses, reduce the bio- 
diversity and domestic animal diversity, as well as jeopardize animal welfares [Udo et al. 2011; Smith et al. 2013]. Manure management in industrialized dairy production is another challenge, because the farms with intensive dairy and meat production do not own sufficient land to receive the animal wastes [Zhang et al. 2017]. Even the biogas production which benefits in GHG-free energy is not a solution to the problem of the excessive amount of manure, because during the anaerobic digestion (AD) process the amount of substrate does not diminish and after the AD process, there is still almost the same amount of digestate to manage.

The animal nutrition which includes applying the best management practices within the cattle production system [Gerber et al. 2013], transition from pasture-based to mixed system [GerssenGondelach et al. 2017; Chobtang et al. 2017] and modification of the dietary composition together with increasing the feed conversion efficiency FCE [Buratti et al. 2017] constitutes another option. Intensification of dairy production in both pasture-based and mixed systems often results in a decrease of GHG emissions but the emissions from mixed systems are generally lower comparing to those from the pasture-based system because of the better feed quality, animal stocking density and animal productivity in mixed systems [Gerssen-Gondelach et al. 2017]. However, in the mixed system, the off-farm inputs in supplementary feed and fertilizers should be considered and efforts should be focused on increasing FCE of brought-in feeds and optimizing the fertilizer use for feed production [Chobtang et al. 2017]. Forage chemical and non-chemical additives may decrease methanogenesis in the animal rumen. Chemical feed additives include alternative electron acceptors like fumarate or inorganic sulphur, halogenated methane analogues, and ionophores [Mathison et al. 1998]; however, these additives may be harmful to animals, may not induce long-term decrease of methanogenesis or may be the origin of antibiotics residues in manure and animal products [Moss et al. 2000]. Therefore, non-chemical additives such as plant secondary metabolites, plant-derived extracts [Greathead 2003; Patra, Saxena 2009] and microalgae [Aemiro et al. 2016] have recently received scientific attention; however, those products still need more long-term in-vivo studies, especially on their gut motoric performance and interactions between individual plant secondary metabolites and their groups [Mendel et al. 2017]. Defaunation, which also reduces methane emission, constitutes another solution [Eugène et al. 2004]. However, those mitigations are expensive or still under investigation. The more common solution could be a modification of animal diet based on maize silage and grains to rations with a lower percentage of concentrate feeds [Zucali et al. 2017].

Manure management is also an extremely important GHG mitigation option and includes best management practices, such as manure covering [Rodhe et al. 2012], application methods (timing, rate, injection), biogas production and other treatment technologies such as cooling slurry [Sommer et al. 2004], composting, enhancing crust formation, adding additional straw to immobilize ammonium-N [Chadwick et al. 2011]. Covering slurry ponds and lagoons with a material oxidizing $\mathrm{CH}_{4}$, such as volcanic soil or garden-waste compost which is rather cheap and easily available substrate, is a promising method. Such biofilter covers remove more than $95 \%$ of $\mathrm{CH}_{4}$ influx [Pratt et al. 2013]. Proper timing, rate and method of injection should be used as best management practices worldwide; however, there are still regions where those simple mitigations are not common [Zhang et al. 2017]. Mechanical separation of the slurry may restrain the emission of $\mathrm{N}_{2} \mathrm{O}$; however, only the application of solid fraction to soil resulted in lower emissions comparing to untreated slurry [Bertora et al. 2008]. The biogas production results in an added value of energy acquired from animal wastes; however, digested slurry should be stored under cover, because of high emission of $\mathrm{CH}_{4}$ [Rodhe et al. 2015]. Composting animal wastes may enhance the GHG emissions during the process [Mulbry, Ahn 2014], while cooling slurry below $15^{\circ} \mathrm{C}$ may be not cost-effective [Dalgaard et al. 2011].

In the farms specialized in crop production, the mitigation targeting the reduction of GHG emissions from soils should be adapted. Arable soils may produce high amounts of $\mathrm{N}_{2} \mathrm{O}$, directly related to the $\mathrm{N}$ inputs and, therefore, precise $\mathrm{N}$ application including better matching crop demand, application variable rates across the field directly within root zone and application timing e.g. close to the moment crops will be able to use, it are the key factors in the strategies of $\mathrm{N}_{2} \mathrm{O}$ emissions mitigation [Paustian et al. 2016; Pellerin et al. 2017]. Another possibility to reduce the $\mathrm{N}_{2} \mathrm{O}$ emissions from fertilized soil is the use of $\mathrm{N}^{2}$ inhibitors, such as dicyandiamide (DCD), 
$\mathrm{N}$-(nbutyl) thiophosphoric triamide (NBPT) or hydroquinone (HQ) which may result in a $50 \%$ reduction of nitrous oxide emissions from soils, comparing to those fertilized with urea. Additionally, the use of chemically altered slow release $\mathrm{N}$ fertilizers lowers the $\mathrm{N}_{2} \mathrm{O}$ emissions by $44 \%$ [Nayak et al. 2015]. Incorporation of animal manure, crop residues and composts into arable land may diminish the amount of mineral $\mathrm{N}$ fertilizers leading to a GHG reduction related to production and use of this fertilizer. Digestate, as a by-product of AD process, is a valuable fertilizer with increased $\mathrm{NH}_{4}^{+}$content and when properly applied to soil, it may also decrease the GHG emissions [Czubaszek, Wysocka-Czubaszek 2018] and at the same time, biogas production decreases the amount of fossil fuels used in agriculture.

\section{CONCLUSIONS}

The methane and nitrous emissions from agriculture differ in 16 voivodeships in Poland. The highest fluxes were calculated for 3 voivodeships (Mazowieckie, Wielkopolskie and Podlaskie) which were responsible for $39 \%$ of national methane and $34 \%$ of national nitrous oxide emissions from agriculture in 1999 and for $51 \%$ and $37 \% \mathrm{CH}_{4}$ and $\mathrm{N}_{2} \mathrm{O}$ national emissions in 2015, respectively. These high amounts of methane and nitrous oxide released from agriculture to the atmosphere are the result of traditionally intensive dairy and beef production in the Mazowieckie and Podlaskie voivodeships, while in the Wielkopolskie voivodeship, high GHG emissions are the effect of both intensive animal and crop production. However, the mitigation should be adapted with caution as there are many interesting possibilities which can reduce the GHG emissions from agriculture. Good management practices may also jointly reduce the environmental burden and costs of animal and crop production. The choice of method should be based on precise calculations and provide both ecological and economic benefits. Mitigation practices may also substantially affect the estimations of GHG emissions in national inventory; however, in this case, further studies on national or even regional EFs are needed.

\section{Acknowledgements}

This work was financially supported by Ministry of Science and Higher Education as a part of the project $\mathrm{S} / \mathrm{WBiIS} / 01 / 17$.

\section{REFERENCES}

1. Aemiro A., Watanabe S., Suzuki K., Hanada M., Umetsu K., Nishida T. 2016. Effects of Euglena (Euglena gracilis) supplemented to diet (forage: concentrate ratios of 60:40) on the basic ruminal fermentation and methane emissions in in vitro conditions. Animal Feed Science and Technology, 212, 129-135.

2. Bajzelj B., Richards K.S., Allwood J.M., Smith P., Dennis J.S., Curmi E., Gilligan C.A. 2014. Importance of food-demand management for climate mitigation. Nature Climate Change, 4, 924-929.

3. Bertora C., Alluvione F., Zavattaro L., van Groenigen J.W., Velthof G., Grignani C. 2008. Pig slurry treatment modifies slurry composition, $\mathrm{N}_{2} \mathrm{O}$, and $\mathrm{CO}_{2}$ emissions after soil incorporation. Soil Biology \& Biochemistry 40, 1999-2006.

4. Buratti C., Fantozzi F., Barbanera M., Lascaro E., Chiorri M., Cecchini L. 2017. Carbon footprint of conventional and organic beef production systems: An Italian case study. Science of the Total Environment, 576, 129-137.

5. Chadwick D., Sommer S., Thorman R., Fangueiro D., Cardenas L., Amon B., Misselbrook T. 2011. Manure management: Implications for greenhouse gas emissions. Animal Feed Science and Technology, 166-167, 514-531.

6. Chobtang J., Ledgard S.F., McLaren S.J., Donaghy D.J. 2017. Life cycle environmental impacts of high and low intensification pasture-based milk production systems: A case study of the Waikato region, New Zealand. Journal of Cleaner Production, 140, 664-674.

7. CSO 2016. Statistical yearbook of agriculture. Central Statistical Office, Warsaw.

8. Czubaszek R., Wysocka-Czubaszek A. 2018. Emissions of carbon dioxide and methane from fields fertilized with digestate from an agricultural biogas plant. Interantional Agrophysics, 32, 29-37.

9. Dalgaard T., Olesen J.E., Petersen S.O., Petersen B.M., Jørgensen U., Kristensen T., Hutchings N.J., Gyldenkærne S., Hermansen J.E. 2011. Developments in greenhouse gas emissions and net energy use in Danish agriculture - How to achieve substantial CO2 reductions? Environmental Pollution, 159, 3193-3203.

10. EPA 2012. Global Anthropogenic Non- $\mathrm{CO}_{2}$ Greenhouse Gas Emissions: 1990 - 2030 EPA 430-R12-006, Office of Atmospheric Programs Climate Change Division U.S. Environmental Protection Agency. Washington DC.

11. Eugène M., Archimède H., Sauvant D. 2004. Quantitative meta-analysis on the effects of defaunation of the rumen on growth, intake and digestion in ruminants. Livestock Production Science, 85, 81-97. 
12. Eurostat 2015. Agriculture - greenhouse gas emission statistics. Eurostat Statistics Explained. http:// ec.europa.eu/eurostat/statistics-explained/index. php/Agriculture_-_greenhouse_gas__emission_ statistics\#Agriculture.27s_contribution.

13. FAO 2016. Agriculture's greenhouse gas emissions on the rise. http:/www.fao.org/news/story/ en/item/216137/icode/.

14. Filipiak K., Ufnowska J. 2002. The regional diferentiation and utilization of agricultural production area in Poland [in Polish]. Pamiętnik Puławski, 130, 153-160.

15. Freibauer A. 2003. Regionalised inventory of biogenic greenhouse gas emissions from European agriculture. European Journal of Agronomy, 19, 135-160.

16. Gerber P.J., Steinfeld H., Henderson B., Mottet A., Opio C., Dijkman J., Falcucci, A., Tempio G. 2013. Tackling climate change through livestock A global assessment of emissions and mitigation opportunities. Food and Agriculture Organization of the United Nations (FAO), Rome.

17. Gerssen-Gondelach S.J., Lauwerijssen R.B.G., Havlík P., Herrero M., Valin H., Faaij A.P.C., Wicke B. 2017. Intensification pathways for beef and dairy cattle production systems: Impacts on GHG emissions, land occupation and land use change. Agriculture, Ecosystems and Environment, 240, 135-147.

18. Greathead H. 2003. Plants and plant extracts for improving animal productivity. Proceedings of the Nutrition Society, 62, 279-290.

19. Hou Y., Velthof G.I. and Oenema O. 2015. Mitigation of ammonia, nitrous oxide and methane emissions from manure management chains: a metaanalysis and integrated assessment Glob. Chang. Biol., 21, 1293-1312.

20. IPCC 2006. IPCC 2006 Guidelines for $\mathrm{Na}$ tional Greenhouse Gas Inventories. The Institute for Global Environmental Strategies (IGES) for the IPCC, http://www.ipcc-nggip.iges.or.jp/ public/2006gl/index.html.

21. IPCC 2014. Climate Change 2014: Mitigation of Climate Change. Working Group III Contribution to the Fifth Assessment Report of the Intergovernmental Panel on Climate Change, Intergovernmental Panel on Climate Change, Cambridge University Press.

22. Isermann K. 1994. Agriculture's share in the emission of trace gases affecting the climate and some cause-oriented proposals for sufficiently reducing this share. Environmental Pollution, 83, 95-111.

23. Kopiński J. 2009. Regionalne zróżnicowanie intensywności organizacji produkcji rolniczej w Polsce. Studia i Raporty IUNG-PIB, 15, 37-49
24. Kulikowski R. 2010. Farm Livestock [in:] Bański J. (ed.) Atlas of Polish agriculture. Stanisław Leszczycki Institute of Geography and Spatial Organization, Polish Academy of Science, Warsaw, 94-111.

25. Leip A., Busto M. and Winiwarter W. 2011. Developing spatially stratified N2O emission factors for Europe Environmental Pollution, 159, 3223-3232.

26. Mathison G.W,. Okine E.K., McAllister T.A., Dong Y., Galbraith J., Dmytruk O. I.N. 1998. Reducing Methane Emissions from Ruminant Animals. Journal of Applied Animal Research, 14(1), 1-28.

27. Mendel M., Chłopecka M., Dziekan N., Karlik W. 2017. Phytogenic feed additives as potential gut contractility modifiers - A review. Animal Feed Science and Technology, 230, 30-46.

28. NCEM 2016. Poland's national inventory report 2016. Greenhouse gas inventory for 1988-2014. Institute of Environmental protection - National Research Institute, The National Centre for Emissions Management. Warsaw.

29. MODR 2007. Development of rural areas. Agriculture of małopolskie voivodship - 2013 [in Polish], Małopolski Ośrodek Doradztwa Rolniczego. http://www.modr.pl/sub.php?mb=4\&t=670.

30. Moss A.R, Jouany J.-P., Newbold J. 2000. Methane production by ruminants: its contribution to global warming. Ann. Zootech., 49, 231-253.

31. Mulbry W., Ahn H. 2014. Greenhouse gas emissions during composting of dairy manure: Influence of the timing of pile mixing on total emissions. Biosystems Engineering, 126, 117-122.

32. Nayak D.R., Adhya T.K., Babu Y.J., Datta A., Ramakrishnan B., Rao V.R. 2006. Methane emission from a flooded field of Eastern India as influenced by planting date and age of rice (Oryza sativa L.) seedlings. Agriculture, Ecosystems and Environment, 115, 79-87.

33. Neufeldt H., Schäfer M., Angenendt E., Li C., Kaltschmitt M., Zeddies J. 2006. Disaggregated greenhouse gas emission inventories from agriculture via a coupled economic-ecosystem model. Agriculture, Ecosystems and Environment, 112, 233-240.

34. Patra A.K., Saxena J. 2009. The effect and mode of action of saponins on the microbial populations and fermentation in the rumen and ruminant production. Nutrition Research Reviews, 22, 204-219.

35. Paustian K., Lehmann J., Ogle S., Reay D., Robertson G.P., Smith P. 2016. Climate-smart soils. Nature, 532, 49-57.

36. Pellerin S., Bamière L., Angers D., Béline F., Benoit M., Butault J.-P., Chenu C., Colnenne-David C., De Cara S., Delame N., Doreau M., Dupraz P., Faverdin P., Garcia-Launay F., Hassouna M., Hénault C., Jeuffroy M.-H., Klumpp K., Metay A., Moran D., Recous 
S., Samson E., Savini I., Pardon L., Chemineau P. 2017. Identifying cost-competitive greenhouse gas mitigation potential of French agriculture. Environmental Science and Policy, 77, 130-139.

37. Pratt C., Deslippe J., Tate K.R. 2013. Testing a biofilter cover design to mitigate dairy effluent pond methane emissions. Environmental Science and Technology, 47(1), 526-532.

38. Rodhe L.K.K., Abubaker J., Ascue J., Pell M., Nordberg Å. 2012. Greenhouse gas emissions from pig slurry during storage and after field application in northern European conditions. Biosystems Engineering, 113, 379-394.

39. Smith A.P., Western A.W., Murray C. Hannah M.C. 2013. Linking water quality trends with land use intensification in dairy farming catchments. Journal of Hydrology, 476, 1-12.

40. Sommer S.G., Petersen S.O.,. Møller H.B. 2004. Algorithms for calculating methane and nitrous oxide emissions from manure management. Nutrient Cycling in Agroecosystems, 69, 143-154.

41. Stuczyński T., Budzyńska K., Gawrysiak L., Zaliwski A. 2000. Waloryzacja rolniczej przestrzeni produkcyjnej Polski. Biuletyn Informacyjny IUNG, 12, 4-17.

42. Turner A.J., Jacob D.J., Wech, K. J., Maasakkers J.D., Lundgren E., Andrews A.E., Biraud S.C., Boesch H., Bowman K.W., Deutscher N.M., Dubey M.K., Griffith D.W. T., Hase F., Kuze A., Notholt J., Ohyama H., Parker R., Payne V.H., Sussmann R., Sweeney C., Velazco V.A., Warneke T., Wennberg P.O. and Wunch D. 2015. Estimating global and North American methane emissions with high spatial resolution using GOSAT satellite data. Atmospheric Chemistry and Physics, 15, 7049-7069.
43. Udo H.M.J., Aklilu H.A., Phong L.T.,. Bosma R.H, Budisatria I.G.S., Patil B.R., Samdup T., Bebe B.O. 2011. Impact of intensification of different types of livestock production in smallholder crop-livestock systems. Livestock Science, 139, 22-29.

44. UN 2017. World population prospects. 2017. Revision. Key Findings and advance tables. United Nations, Department of Economic and Social Affairs, Population Division, ESA/P/WP/248, New York.

45. UNFCCC 1997. Kyoto Protocol to the United Nations Framework Convention on Climate Change.

46. Verge X.P.C., De Kimpe C., Desjardins R.L. 2007. Agricultural production, greenhouse gas emissions and mitigation potential. Agricultural and Forest Meteorology, 142, 255-269.

47. Yusuf R.O, Noor Z.Z., Abba A.H., Hassan M.A.A., Din M.F.M. 2012. Methane emission by sectors: A comprehensive review of emission sources and mitigation methods. Renewable and Sustainable Energy Reviews, 16, 5059-5070.

48. Zhang N., Bai Z., Luo J., Ledgard S., Wu Z., Ma L. 2017. Nutrient losses and greenhouse gas emissions from dairy production in China: Lessons learned from historical changes and regional differences. Science of the Total Environment, 598, 1095-1105.

49. Zhou J.B., Jiang M.M. and Chen G.Q. 2007. Estimation of methane and nitrous oxide emission from livestock and poultry in China during 1949-2003. Energy Policy, 35, 3759-3767.

50. Zucali M., Tamburini A., Sandrucci A., Bava L. 2017. Global warming and mitigation potential of milk and meat production in Lombardy (Italy). Journal of Cleaner Production, 153, 474-482. 